\title{
SKIRTINGUU FIZINIO AKTYVUMO KATEGORIJŲ PAAUGLIŲ SU SVEIKATA SUSIJUSIO FIZINIO PAJËGUMO POKYČIAI PER VIENUS METUS
}

\author{
Arūnas Emeljanovas, Vida Volbekienė, Renata Rutkauskaitė, Edita Maciulevičienė, \\ Rita Sadzevičienè, Olegas Batutis \\ Lietuvos kūno kultūros akademija, Kaunas, Lietuva
}

Arūnas Emeljanovas. Biomedicinos mokslų daktaras. Lietuvos kūno kultūros akademijos Kūno kultūros ir gimnastikos katedros vedèjas, lektorius. Mokslinių tyrimų kryptis - skirtingų fizinių krūvių poveikis paauglių organizmui, mokinių fizinio aktyvumo problematika.

\section{SANTRAUKA}

Nors fizinis pajegumas genetiškai determinuotas, ji lemia ir aplinkos veiksniai, iš kuriu vienas svarbiausiu — fizinis aktyvumas. Priklausomai nuo fizinio aktyvumo intensyvumo poveikis gali būti skirtingas. Suaugusiujufizinio aktyvumo (FA) teigiamas poveikis fiziniam pajègumui ir svarbiausiems sveikatos rodikliams plačiai tyrinètas, tačiau duomenu apie vaiku ir paaugliu fizini aktyvuma, fizini pajèguma stokojama.

Tyrimo tikslas — nustatyti skirtingu fizinio aktyvumo kategoriju 15 ir 16 metu berniuku su sveikata susijusio fizinio pajëgumo pokyčius per vienus metus. Tyrimas buvo vykdomas $2008 \mathrm{~m}$. (I tyrimas) ir $2009 \mathrm{~m}$. (II tyrimas) kovo-balandžio mènesiais atsitiktiniu büdu atrinktose keturiose Kauno miesto bendrojo lavinimo mokyklose. Tiriamaja imti sudare 118 devintu klasiu berniuku, kurie pagal ju sveikatos bükle yra priskirti pagrindinei fizinio ugdymo grupei. Mokiniu fizinis aktyvumas nustatytas interviu metodu pagal modifikuota tarptautinio FA (IPAQ) klausimyno trumpaja forma (Ainsworth, Levy, 2004). Visi respondentai pagal FA apimti buvo suskirstyti i 3 FA kategorijas (Guidelines for Data Processing and Analysis of the International Physical Activity Quostionnaire (IPAQ) Short and Long Forms, 2005): didelio FA (DFA) ( $\geq 3001$ MET'os-min / sav.), vidutinio FA (VFA) (> $1387<3001$ MET'os-min / sav.) ir mažo

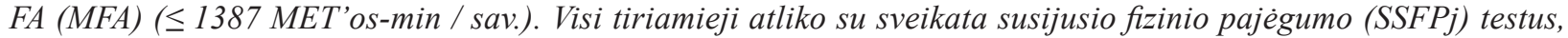
kuriais buvo nustatytas raumenu pajegumas: koju raumenu staigioji jejga — atliekant vertikalius šuolius $\dot{\jmath}$ aukštti iš vietos su ranku mostu (naudotas matuoklis SBM-1, fiksuojamas geriausias rezultatas iš 3), ranku ir liemens raumenu ištvermé — atliekant modifikuotus atsispaudimus (Suni et al., 1994), lankstumas išmatuotas „, Séstis ir siekti“ testu (Eurofit, 1993). Identiškas fizinio pajègumo tyrimas pakartotas 2009 m. kovo—balandžio mènesiais, tačiau dèl objektyviu priežasčiu buvo tiriami tik 56 tiriamieji iš 118 (I tyrimas). Tyrimo duomenims palyginti taikyta vienfaktorine dispersine analizé, Stjudento $t$ (Student t) kriterijus taikytas priklausomoms imtims ir atlikta kovariacine analizé.

Gauti rezultatai parodè, kad didèjant fizinio aktyvumo apimčiai tiesiškai gerèja paaugliu raumenu pajègumas — ranku ir liemens raumenu ištvermès bei koju raumenu staigioji jëga $(p<0,05)$. Lankstumo rezultatu pokyčiai didèjant fiziniam aktyvumui statistiškai nereikšmingi $(p>0,05)$.

Raktažodžiai: fizinis pajëgumas, fizinis aktyvumas, sveikata.

\section{IVADAS}

$\mathrm{R}$ emiantis pagrindine fizinio aktyvumo (FA) ir sveikatos sąsajos paradigma, FA poveikis sveikatai gali būti dvejopas: tiesioginis - FA tiesiogiai veikia sveikatą, ir netiesioginis - FA sukelia fizinio pajègumo pokyčius, o šie veikia sveikatą. Tiesioginis ir netiesioginis FA poveikis sveikatai priklauso nuo bendrosios FA apimties (toliau FA apimtis), kurios sandai yra FA intensyvumas, trukmė ir dažnis. Taigi FA matas yra išeikvota energija (matuojama metomis) per tam tikrą laiką, dažniausiai minutėmis per savaitę
(MET'os-min / sav.) (Haskell, 1994; Howley, 2001). Mokslinių publikacijų autoriai nagrinèdami, kokia FA apimtis (dozè) sukelia siekiamą specifini sveikatos rezultatą (atsaką), vartoja termina dozé-atsakas (doze - patiriama FA apimtis, atsakas - sveikatos požymio, pavyzdžiui, aerobinio pajègumo pokytis, kaip patirto fizinio aktyvumo pasekmè) (Howley, 2001).

Fizinis pajègumas $(\mathrm{FPj})$ - igimtu ir fizinio aktyvumo nulemtu su sveikata ir judejjimo gebèjimais / igūdžiais susijusių požymių visuma. Su 
sveikata susijusio fizinio pajègumo (SSFPj) komponentai (kūno kompozicija, lankstumas, širdies ir kraujagyslių sistemos ištvermé, griaučių raumenų ištvermè ir jẻga, vis dažniau prie šių komponentu priskiriama staigioji jèga) yra daug reikšmingesni visuomenès sveikatai negu su judejjimo igūdžiais susijusio FPj komponentai (vikrumas, pusiausvyra, koordinacija, greitumas, reakcijos trukmè). Pastarieji komponentai netiesiogiai veikia sveikatos būklę, o tiesiogiai - sportinius / atletinius laimèjimus, rezultatus (Howley, 2001).

Fizinio aktyvumo nauda sveikatai, ypač suaugusiujuc, pagrissta daugelio mokslinių tyrimų (Matton et al., 2006). Tyrimais nustatyta FA nauda vaikų, jaunimo širdies ir kraujagyslių sistemai, medžiagu apykaitai, griaučiu raumenu pajègumui ir psichikos sveikatai - fiziškai aktyvių moksleivių didesnis savigarbos, mažesnis nerimo ir streso lygis (Strong et al., 2005; Horst et al., 2007). Nepakankamas jaunimo FA ir SSFPj yra susijęs su išeminès širdies ligos rizikos veiksniais (Katzmarzyk et al., 1999). Tarp FA apimties ir FPj, aerobinio pajègumo ir nutukimo, sergamumo širdies ir kraujagysliu sistemos ligomis nustatytas ryšys (Church et al., 2007; Ortega et al., 2008). Su amžiumi mažěja vaiku FA, dèl to prasteja širdies ir kraujagysliu sistemos pajègumas (Dollman, Olds, 2007). Nors klausimas diskusinis, daugelio tyrimu rezultatai rodo, kad vaiku ir paaugliu FA ir FPj lygis turi itakos sveikatai suaugus (Malina, 2001; Matton et al., 2006). Pasyvi gyvensena, nepakankamas FPj vaikysteje bei paauglystėje gali būti širdies ir kraujagyslių ligų, nutukimo grèsmès suaugus priežastis. Ištirta, kad FA ir FPj paauglysteje turi dvejopą — laikiną ir ilgalaiki poveiki sveikatai (Lohman et al., 2008). Manoma, kad FPj yra integruotas daugumos, jeigu ne visų, organizmo funkcijų, susijusių su FA, matmuo (Ortega et al., 2008). Taigi testuojant FPj iš tikruju patikrinama didžioji dalis organizmo fiziologiniu funkcijų. FPj pripažisstamas kaip svarbus sveikatos rodmuo, taip pat sergamumo ir mirtingumo dèl lètinių ligų veiksnys (Ortega et al., 2008; Lohman et al., 2008).

Nors FA ir FPj ryšiai su sveikata pagrịsti gausiais epidemiologiniais tyrimais, daugelio vaiku ir paaugliu kasdienis fizinis aktyvumas yra nepakankamas, neatitinka sveikatą stiprinančio FA tarptautinių rekomendacijų (ne mažesnis kaip 1 valandos trukmès nuo vidutinio iki didelio intensyvumo FA kiekvieną diena) (Strong et al., 2005; ACSM, 2002). Remiantis šiomis rekomendacijomis nustatyta, kad JAV, Kanadoje, Europoje, esant skirtingam amžiui ir lyčiai grupèse, maždaug viena trečioji dalis moksleiviu yra pakankamai fiziškai aktyvūs, t. y. didžiujų miestų 5-11 klasių mokiniai praktikuoja sveikatą stiprinanti FA (Sulemana et al., 2006; Tammelin et al., 2007; Atkin et al., 2008), Lietuvoje - 14,2\% (iš jų 9,8\% mergaičiu ir 18,6\% berniukų) (Volbekienè ir kt., 2007).

Be to, mokyklinio amžiaus vaikų SSFPj ir jo kitimo tendencijos yra negatyvios. Europoje ir JAV daugèja vaikų, turinčių antsvorị, jų širdies ir kraujagyslių sistemos, taip pat raumenų pajėgumas yra nepakankami ir turi tendenciją neigiamai kisti (Westerstahl et al., 2003; Wedderkopp et al., 2004). Mūsų atliktų tyrimų rezultatai taip pat rodo Lietuvos paauglių širdies ir kraujagysliu sistemos, iš dalies ir raumenu pajègumo bei lankstumo negatyvų kitimą 1992-2002 m. (Volbekiene, Griciute, 2007).

Nors prevenciniu ir reabilitaciniu požiūriu FA ir FPj nauda sveikatai įrodyta, lieka neatsakyta $i$ klausima, kokios apimties fizinio aktyvumo reikia tam tikram efektui pasiekti? Atsakymas turi pagrịstai nusakyti FA apimtị ir rūšį, reikalingą prognozuojamam FPj lygiui pasiekti (Howley, 2001). Literatūroje dar labai trūksta tyrimų duomenų apie vaikų ir jaunimo FA ir SSFPJ dozèsatsako ryšius, skirtingos FA apimties lemtus SSFPj kitimo dessningumus (Tammelin et al., 2007). Tokio pobūdžio tyrimai turètų suteikti vertingą informaciją apie veiksmingą FA apimti stiprinant SSFPj komponentus, turètų reikšmès jaunimo FA didinimo, kartu ir sveikatos stiprinimo strategijos kūrimui bei plètotei (Horst et al., 2007).

Šio tyrimo tikslas - nustatyti skirtingu fizinio aktyvumo kategoriju 15 ir 16 metų berniuku su sveikata susijusio fizinio pajègumo pokyčius per vienus metus.

\section{TYRIMO METODIKA}

Tyrimas buvo vykdomas $2008 \mathrm{~m}$. (I tyrimas) ir 2009 m. (II tyrimas) kovo-balandžio mènesiais atsitiktiniu būdu atrinktose keturiose Kauno miesto bendrojo lavinimo mokyklose. Kauno miesto bendrojo lavinimo mokyklų atrankoje nedalyvavo mokyklos, esančios už miesto ribų, ir specialiosios (pvz., profesinès, nacionalinių mažumų). Pirmo tyrimo metu mokiniai buvo atrinkti patogiosios atrankos būdu, t. y. atsižvelgiant į mokyklos administracijos sudarytas galimybes. Tiriamaja imti sudare visi, t. y. 134 devintu klasių berniukai, kurie pagal sveikatos būklę yra priskirti pagrindinei fizinio ugdymo grupei. Atliekant statistinę rezultatu analizę, iš tiriamosios imties buvo išskirti 118 berniuku, kurie atitiko visus tyrimo reikalavimus: savano- 
riškai sutiko ir gavo tèvų leidimą dalyvauti tyrime bei publikuoti tyrimo rezultatus, fizinio aktyvumo anketose pateikè visus fizinio aktyvumo apimties nustatymui reikalingus duomenis ir atliko visus tyrimo programoje numatytus fizinio pajëgumo testus. Identiškas tyrimas vietos ir tiriamosios imties atžvilgiu pakartotas 2009 m., tačiau dèl objektyviu priežasčių pasikeitè tiriamujų imties dydis. Tiriamosios imties sumažejjimą per II tyrimą lèmè mokiniu perejjimas mokytis i kitas mokyklas dèl švietimo reformos, gyvenamosios vietos kaita ir mokiniu emigravimu su šeima ị kitas valstybes. Taigi ilgalaikio SSFPj tyrimo statistinei rezultatu analizei atlikti panaudoti 56 tiriamuju SSFPj duomenys. I tyrimo metu nustatyti skirtingų FA kategorijų berniukų FA ir SSFPj, II - tos pačios tiriamosios imties SSFPj rezultatų pokyčiai nuo I iki II tyrimo.

Mokiniu fizinis aktyvumas nustatytas interviu metodu pagal modifikuotą tarptautinio FA (IPAQ) klausimyno trumpają formą (Ainsworth, Levy, 2004). Anketą sudaro keturios dalys, pagal kurias buvo nustatytas FA intensyvumas metomis (MET'a), dažnumas - dienomis per savaitę (d. / sav.), trukmé (registruojama tik ilgesnè kaip10 min) - minutemis per vieną dieną (min / d.). Respondentu FA apimtis per savaitę nustatyta skaičiuojant išeikvotą energijos kieki (MET'os-min / sav.). Visi respondentai pagal FA apimti buvo suskirstyti i 3 FA kategorijas (Guidelines for Data Processing and Analysis of the International Physical Activity Quostionnaire (IPAQ) Short and Long Forms (2005)): didelio FA (DFA) ( $\geq 3001$ MET'os-min / sav.), vidutinio FA (VFA) $(>1387<3001$ MET'os-min / sav.) ir mažo FA (MFA) ( $\leq 1387$ MET'os-min / sav.).

SSFPj nustatytas matuojant šiuos komponentus: kūno kompoziciją - KMI $\left(\mathrm{kg} / \mathrm{m}^{2}\right)$, riebalinio audinio kieki (\%) ir liesają kūno masę $(\mathrm{kg})$; raumenu pajègumą - kojų raumenu staigiaja jègą $(\mathrm{cm})$, ranku ir liemens raumenų ištvermę (n / $40 \mathrm{~s})$; lankstumą $(\mathrm{cm})$. Išmatavus svorị $(\mathrm{kg})$ ir ūgi $(\mathrm{cm})$, KMI nustatytas standartiniu būdu $\left(\mathrm{kg} / \mathrm{m}^{2}\right)$; riebalinio audinio kiekis $(\%)$ ir liesoji kūno masè $(\mathrm{kg})$ - bioelektrinès varžos (BIA) metodu (naudojant kūno kompozicijos analizatoriu Tanita BC-418MA). Raumenų pajègumas nustatytas testais: kojų raumenų staigioji jèga — atliekant vertikalų šuoli i aukšti iš vietos su rankų mostu (naudotas matuoklis SBM-1, fiksuojamas geriausias rezultatas iš trijų), rankų ir liemens raumenu ištvermè - atliekant modifikuotus atsispaudimus (Suni et al., 1994). Lankstumas išmatuotas „Sèstis ir siekti“" testu (Eurofit, 1993).
Visi tirti berniukai supažindinti su tyrimo tikslu, anketos turiniu, jos pildymo eiga, SSFPj testu atlikimo metodika. Specialiai parengta kvalifikuota tyrèjų grupė atliko anketinę apklausą ir nustate mokinių SSFPj. Tyrimai atlikti remiantis bendradarbiavimo sutartimis tarp Lietuvos kūno kultūros akademijos ir bendrojo lavinimo mokyklų dèl moksleiviu fizinio aktyvumo ir fizinio pajegumo tyrimų. Buvo gautas Biomedicininių tyrimu etikos komiteto leidimas.

Tiriamosios imties homogeniškumas nustatytas palyginus tiriamujų amžių ir kūno kompozicijos ypatumus (1 lent.).

Matematinès statistikos metodai. Skirtumai tarp įvairių FA kategorijų tiriamujų imties amžiaus ir kūno kompozicijos rezultatų per I ir II tyrimą nustatyti vienfaktorinès dispersinès analizès būdu. I ir II tyrimų kojų raumenų staigiosios jègos, rankų ir liemens raumenu ištvermès bei lankstumo rezultatai palyginti taikant Stjudento t kriteriju priklausomoms imtims. Norint nustatyti šių raumenu pajëgumo ir lankstumo rezultatu pokyčius nuo I iki II tyrimo tarp skirtingų FA kategorijų, buvo taikyta kovariacinè analizè. Priklausomas kintamasis kovariacinès analizès metu buvo kiekvieno iš paminètu rodikliu pokytis, faktorius - FA kategorija, kovariante - FPj analizuojamų rodikliu rezultatai I tyrimo metu. Pagrindinè hipotezè suvienodinus pradini FPj rodiklių lygi, kiekvieno rodiklio pokytis tiesiškai didèja gerèjant fiziniam aktyvumui (tikrinama naudojant tiesini kontrastą) (Čekanavičius, Murauskas, 2002). Naudoti tokie statistiniu išvadų patikimumo lygiai: $p>0,05-$ nepatikima; $\mathrm{p}<0,05$ - patikima. Visi skaičiavimai atlikti MS Excell ir SPSS kompiuterinėmis programomis.

\section{REZULTATAI}

Palyginus tiriamosios imties amžiu, ūgio, svorio ir kūno kompozicijos rezultatus (1 lent.), nustatytas tiriamosios imties homogeniškumas tarp skirtingu FA kategorijų tiriamujų per I ir II tyrima $(p=0,202-0,989)$. Pirmo ir antro tyrimo metu tiriamujų ūgis ir kūno kompozicijos komponentai statistiškai reikšmingai nesiskyrè $(p>0,05)$.

Norint nustatyti fizinio pajègumo komponentu pokyčius skirtingų fizinio aktyvumo kategoriju tiriamieji pagal pirmo tyrimo fizinio aktyvumo duomenis buvo suskirstyti i FA grupes. Bendroji FA apimtis (MET'os-min / sav.) pirmo ir antro tyrimo metu tarp FA grupiu nebuvo skirtinga $(p>0,05)$. 


\begin{tabular}{|c|c|c|c|c|c|}
\hline \multirow[b]{2}{*}{ Rodiklis } & \multirow{2}{*}{$\begin{array}{c}\text { Tyrimas } \\
(2008-\text { I, } \\
2009-\text { II })\end{array}$} & \multicolumn{3}{|c|}{ FA kategorijos $(\bar{x} \pm \mathrm{SN})$} & \multirow[b]{2}{*}{$\mathbf{F}$} \\
\hline & & MFA $(n=21)$ & $\begin{array}{c}\text { VFA } \\
(n=21)\end{array}$ & $\begin{array}{c}\text { DFA } \\
(\mathrm{n}=14)\end{array}$ & \\
\hline \multirow{2}{*}{ Amžius, m. } & $\mathrm{I}$ & $15,14 \pm 0,35$ & $15,19 \pm 0,51$ & $15,29 \pm 0,46$ & 0,429 \\
\hline & II & $16,14 \pm 0,35$ & $16,14 \pm 0,47$ & $16,21 \pm 0,57$ & 0,123 \\
\hline \multirow{2}{*}{ Ūgis, cm } & I & $177,62 \pm 6,94$ & $177,29 \pm 7,21$ & $178,93 \pm 4,32$ & 0,283 \\
\hline & II & $180,29 \pm 6,14$ & $180,29 \pm 6,80$ & $180,57 \pm 4,83$ & 0,011 \\
\hline \multirow{2}{*}{ Svoris, kg } & I & $64,17 \pm 11,11$ & $62,29 \pm 8,13$ & $66,16 \pm 5,94$ & 0,794 \\
\hline & II & $65,40 \pm 10,72$ & $64,81 \pm 8,42$ & $69,25 \pm 6,17$ & 0,794 \\
\hline \multirow{2}{*}{ KMI, $\mathrm{kg} / \mathrm{m}^{2}$} & I & $20,21 \pm 2,61$ & $19,81 \pm 2,35$ & $20,65 \pm 1,44$ & 1,153 \\
\hline & II & $20,20 \pm 2,56$ & $20,01 \pm 2,31$ & $21,28 \pm 1,30$ & 1,516 \\
\hline \multirow{2}{*}{$\begin{array}{l}\text { Riebalinis } \\
\text { audinys, \% }\end{array}$} & I & $15,81 \pm 3,82$ & $14,34 \pm 3,81$ & $15,06 \pm 2,77$ & 0,876 \\
\hline & II & $15,40 \pm 3,71$ & $13,78 \pm 3,70$ & $15,70 \pm 2,70$ & 1,649 \\
\hline \multirow{2}{*}{$\begin{array}{l}\text { Liesoji kūno } \\
\text { masè, kg }\end{array}$} & I & $53,67 \pm 7,18$ & $53,18 \pm 5,83$ & $56,08 \pm 3,6$ & 1,080 \\
\hline & II & $55,08 \pm 7,36$ & $55,76 \pm 6,43$ & $57,89 \pm 4,14$ & 0,862 \\
\hline
\end{tabular}

1 lentelè. Tiriamosios imties apibūdini$\operatorname{mas}(\bar{x} \pm \mathrm{SN})$

\begin{tabular}{|c|c|c|c|c|c|c|}
\hline \multirow[t]{2}{*}{ FA kategorijos } & \multicolumn{2}{|c|}{ Tyrimas } & \multicolumn{2}{|c|}{$\begin{array}{c}\text { Stjudento t } \\
\text { kriterijus }\end{array}$} & \multicolumn{2}{|c|}{$\begin{array}{c}\text { Kovariacinè } \\
\text { analizé } \\
\end{array}$} \\
\hline & $\mathbf{I}$ & II & $\mathbf{t}$ & $\mathbf{p}$ & $\mathbf{F}$ & $\mathbf{p}$ \\
\hline \multicolumn{7}{|c|}{ Kojų raumenų staigioji jèga, cm } \\
\hline $\operatorname{MFA}(\mathrm{n}=21)$ & $38,87 \pm 6,87$ & $39,81 \pm 4,15$ & 0,799 & 0,434 & \multirow{3}{*}{2,207} & \multirow{3}{*}{$0,036^{*}$} \\
\hline $\operatorname{VFA}(\mathrm{n}=21)$ & $40,51 \pm 7,99$ & $42,28 \pm 6,72$ & 1,329 & 0,199 & & \\
\hline DFA $(n=14)$ & $45,27 \pm 7,50$ & $45,92 \pm 4,04$ & 0,468 & 0,647 & & \\
\hline \multicolumn{7}{|c|}{ Lankstumas, cm } \\
\hline MFA $(n=21)$ & $16,0 \pm 5,84$ & $18,02 \pm 7,02$ & 1,756 & 0,094 & \multirow{3}{*}{1,306} & \multirow{3}{*}{0,412} \\
\hline $\operatorname{VFA}(\mathrm{n}=21)$ & $19,33 \pm 6,23$ & $20,95 \pm 8,42$ & 1,016 & 0,322 & & \\
\hline DFA $(n=14)$ & $20,64 \pm 6,02$ & $23,43 \pm 7,42$ & 1,767 & 0,101 & & \\
\hline \multicolumn{7}{|c|}{ Rankų ir liemens raumenų ištvermė, n / 40s } \\
\hline $\operatorname{MFA}(\mathrm{n}=21)$ & $17,14 \pm 4,74$ & $19,95 \pm 4,01$ & 2,352 & $0,029 *$ & \multirow{3}{*}{2,934} & \multirow{3}{*}{$0,003 *$} \\
\hline $\operatorname{VFA}(\mathrm{n}=21)$ & $19,19 \pm 6,9$ & $22,1 \pm 4,26$ & 2,049 & 0,054 & & \\
\hline $\operatorname{DFA}(n=14)$ & $20,86 \pm 6,11$ & $24,86 \pm 3,11$ & 2,438 & $0,030^{*}$ & & \\
\hline
\end{tabular}

2 lentelè. Berniukų su sveikata susijusio fizinio pajègumo rezultatai $(\bar{x} \pm \mathrm{SN})$
Fizinio pajėgumo rodikliai, jų kitimas priklausomai nuo fizinio aktyvumo kategorijos pateiktas 2 lentelëje. Pirmo tyrimo metu tarp nevienodo FA grupių buvo nustatyti kojų raumenų staigiosios jègos rodiklių $(\mathrm{p}<0,05)$, antro tyrimo metu kojų raumenų staigiosios jẻgos, rankų ir liemens raumenų ištvermès rodiklių $(\mathrm{p}<0,05)$ skirtumai.

Visų tiriamujų vidutiniai fizinio pajègumo rodikliai per tiriamaji laikotarpi didejo, tačiau reikšmingai pakito tik mažo ir didelio FA grupés tiriamujų rankų ir liemens raumenų ištvermé $(\mathrm{p}<0,05)$. Visose fizinio aktyvumo grupèse labiausiai pagerejo jègos ištvermès kintamasis (modifikuotų atsispaudimų testų rezultatai), mažiausiai pakito staigioji jèga (šuolio ił aukštị rezultatai).

Papildomai atlikta kovariacinè analizè, kurios metu fizinio pajègumo komponentų pokyčiai buvo skaičiuojami ir lyginami tarp skirtingo fizinio aktyvumo kategorijų tiriamuju suvienodinus (matematiškai) fizinio pajègumo komponentų pradinius lygius (žr. pav.). Analizuojant kiekvieną fizinio pajègumo komponentą, kovariantè buvo pradinè to fizinio komponento reikšmé, o fizinio aktyvumo grupèse lyginami pokyčių vidurkiai, kurie būtu, jei visose fizinio aktyvumo grupèse analizuojamo komponento vidurkiai tyrimo pradžioje būtų vienodi. Matematiškai koreguotos vidurkių reikšmès buvo didžiausios didelio FA grupèse, mažiausios - mažo FA grupėse, netgi kojų raumenų staigiosios jègos ji nustatyta minusinè $(-0,241)$. Pastebeta ir rezultatu kitimo pozityvi tendencija, tačiau reikšmingi skirtumai nustatyti tik MFA ir DFA grupèse tarp berniuku ranku ir liemens raumenu ištvermès rezultatu $(p<0,05)$. Kojų raumenų staigiosios jègos ir rankų bei liemens raumenų ištvermès rezultatų pokyčiai tiesiškai didèja gerèjant FA (atitinkamai $\mathrm{p}=0,036$ ir $\mathrm{p}=0,003)$; lankstumo rezultatų pokyčiai - statistiškai nereikšmingi $(p=0,412)$. Didžiausias FA lygio efektas nustatytas rankų ir liemens raumenų 
Pav. Su sveikata susijusio fizinio pajègumo rodiklių kaita kintant fizinio aktyvumo apimčiai

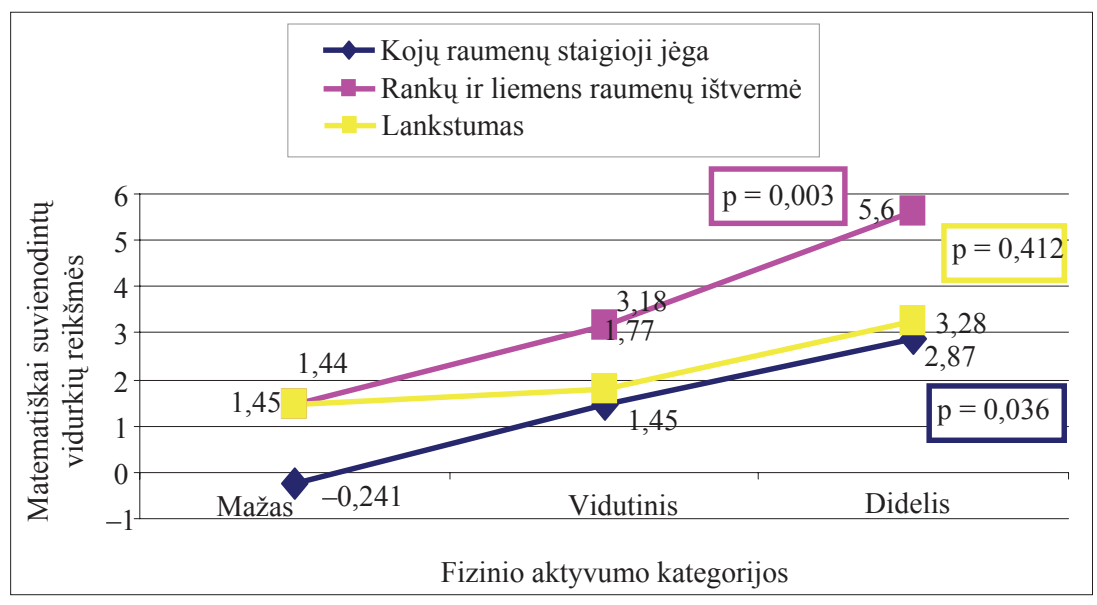

ištvermès rezultatų pokyčio $\left(\eta^{2}=0,157\right)$, mažesnis - kojų raumenų staigiosios jègos $\left(\eta^{2}=0,085\right)$, mažiausias - lankstumo $\left(\eta^{2}=0,014\right)$.

\section{REZULTATU APTARIMAS}

Šiuo tyrimu nustatyti mažo, vidutinio ir didelio FA kategoriju 15 ir 16 metu berniuku SSFPj ir jų pokyčiai. Pagrindinè išvada yra ta, kad tarp FA apimties ir griaučių raumenų pajėgumo egzistuoja tiesine priklausomybè, t. y. didejjant FA reikšmingai gereja vertikalaus šuolio ir modifikuotu atsispaudimu rezultatai, o tarp FA apimties ir lankstumo išryškejja tik rezultatų analogiško kitimo tendencija ( $p>0,05)$. Mūsų nuomone, tokius pokyčius galima paaiškinti genetinių ir aplinkos veiksnių itaka. Kaip žinoma, FPj kinta dèl FA, tačiau FPj atsaką i patiriamą FA itin daug lemia genetinis paveldimumas (Malina et al., 2004). Vadinasi, kiekvieno asmens FPj adaptacijos lygis esant vienodai FA dozei gali būti skirtingas. Tai nepanaikina FA reikšmingumo stiprinant ir / ar palaikant FPj bei sveikatą (Ortega et al., 2008). Mūsų tyrimo rezultatus galejjo lemti ir tokie veiksniai kaip mityba, žalingi gyvensenos ipročiai, sveikos elgsenos, pavyzdžiui, streso kontrolès igūdžiai. Šie veiksniai pavieniui ir / arba kompleksiškai veikia FPj morfologini, raumenų pajègumo, širdies ir kraujagyslių, taip pat kvẻpavimo sistemu, judejjimo (motorini) ir medžiagu apykaitos komponentus (Blair et al., 2001).

Nors gausu mokslinių publikacijų apie FA ir sveikatą (vien pubMed duomenų bazès paieška pateikia daugiau nei 10000 straipsnių pavadinimu su terminais fizinis aktyvumas, fizinis pajegumas, sveikata arba kitais su jais susijusiais reikšminiais žodžiais), tačiau stokojama vaiku ir jaunimo FA ir SSFPj ryšio, ypač dozės - atsako mokslinių tyrimu (Ortega et al., 2008; Oja, 2001). Esamoje mokslinèje literatūroje dèl nereprezentatyvios tiriamuju imties, svarbiausia — dèl FA bei FPj tyrimų metodu ¡̇vairovès, kartais ir dèl objektyvumo stygiaus pateikiami tyrimu rezultatai yra prieštaringi (Lohman et al., 2008). Tyrimais nustatyti vaikų ir jaunimo FA pozityvūs ryšiai su FPj lygiu ir negatyvūs — su riebalų kiekiu organizme, širdies ir kraujagyslių sistemos rizikos veiksniais (Ortega et al., 2008). Taip pat tyrimų rezultatai rodo, kad FA nepriklauso nuo antropometriniu matmenų ir silpnai koreliuoja su fiziniais gebejjimais, îskaitant lankstumą bei raumenų pajègumą (Saar, Jurimae, 2004).Vis dèlto ilgalaikių tyrimų rezultatai, priešingai nei paminèti, rodo pozityvu paaugliu kasdienio fizinio aktyvumo poveikị raumenų pajègumui. Daugèja tyrimu, kurių rezultatai pagrindžia nuo ankstyvos vaikystės patiriamo kasdienio fizinio aktyvumo reikšmę SSFPj komponentams (širdies ir kraujagyslių sistemai, raumenų pajègumui), judesių igūdžiams, širdies ir kraujagyslių sistemos ligu prevencijai, taip pat FA apimties ir SSFPj ryši (Strong et al., 2005; Ortega et al., 2008; Volbekiené ir kt., 2008). Taigi, kai kurių autorių nuomone, su sveikata susijęs fizinis pajègumas, kaip reikšmingas sveikatos, ypač širdies ir kraujagyslių būklès rodmuo, turètų būti ịtrauktas ị sveikatos patikros sistemą (Ruiz et al., 2006).

FA poveikis sveikatai, SSFPj komponentams priklauso nuo FA apimties ir nèra adekvatus visais atvejais. Labiausiai pagristos ir Pasaulio sveikatos organizacijos pripažintos vaikų ir jaunimo fizinio aktyvumo rekomendacijos yra tokios: ne mažesnis kaip 60 minučiu trukmès (nuo vidutinio iki didelio intensyvumo) FA kiekvieną dieną (t. y. išeikvojant nuo 6 iki $8 \mathrm{kcal} / \mathrm{kg}$ per dieną) (ACSM, 2002). Tyrimų rezultatai rodo, kad didesnio intensyvumo vaikų ir paauglių FA labiau nei mažo intensyvumo veikia širdies ir kraujagyslių sistemos pajègumą, svarbus nutukimo prevencijai (Ruiz et al., 2006). Nepriklausomai nuo amžiaus, brandos ir lyties mokiniai, kuriu FA yra nuo vidutinio iki didelio intensyvumo ir trunka ne mažiau kaip 60 minučiu kiekvieną dieną, yra geresnès sveikatos, didesnis 
jų SSFPj. Moksliniais tyrimais nustatyta, kad neigiamą su amžiumi atsirandantį vaikų aerobinio pajègumo kitimą, būdingą ir Lietuvos moksleiviams (Volbekiene, Griciute, 2007), gali stabilizuoti arba negatyvų kitimą pakeisti pozityviu kasdienis vidutiniškai intensyvus FA (Malina et al., 2004).

Vienas svarbiausių vaikų ir paauglių sveikatos stiprinimo ir ligu prevencijos strategijos elementu turi būti FA skatinimas, pabrèžiant intensyvumo dydi. FPj testavimas turètu papildyti ne tik suaugusiujų, bet ir vaikų, paauglių sveikatos priežiūros sistemą (Strong et al., 2005; Ortega et al., 2008; Saar, Jurimae, 2004). FPj gerinimas, didinant vidutinio intensyvumo FA trukmę, turètų būti vienas iš svarbiausių sveikatos stiprinimo politikos tikslų.
FA programos turi būti skirtos kiekvieno SSFPj komponento, suteikiant prioritetus aerobinio raumenų pajègumo stiprinimui ir svorio kontrolei, o jų veiksmingumas patvirtintas ilgalaikiais ir eksperimentiniais tyrimais (Strong et al., 2005; Ortega et al., 2008).

\section{IŠVADOS}

Didejjant fizinio aktyvumo apimčiai, tiesiškai dideja paaugliu raumenu pajègumo - ranku ir liemens raumenų ištvermès bei kojų raumenų staigiosios jègos - pokyčiai $(\mathrm{p}<0,05)$. Lankstumo rezultatu pokyčiai didejjant fiziniam aktyvumui statistiškai nereikšmingi $(\mathrm{p}>0,05)$.

\section{LITERATŪRA}

ACSM. (2002). How much exercise is enough? Sports Medicine Bulletin, 37, 6, 5-6.

Ainsworth, B. E., Levy, S. S. (2004). Assessment of health-enhancing physical activity: Methodological issues. In P. Oja, J. Borms (Eds.), Health Enhancing Physical Activity. Perspectives - the Multidisciplinary Series of Physical Education and Sport Science, 6 (pp. 239-270). Oxford (UK): Meyer \& Meyer Sport Ltd.

Atkin, A. J., Gorely, T., Biddle, S. J. H., Marshall, N. C. (2008). Critical hours: Physical activity and sedentary behavior of adolescents after school. Pediatric Exercise Science, 20 (4), 446-56.

Blair, S. N., Cheng, Y., Holder, J. S. (2001). Is physical activity or physical fitness more important in defining health benefits? Medicine and Science in Sport and Exercise, 33 (6), 379-399.

Church, T. S., Earnest, C. P., Skinner, J. S., Blair, S. N. (2007). Effects of different doses of physical activity on Cardiorespiratory Fitness among sedentary, overweight or obese postmenopausal women with elevated blood pressure: A randomized controlled trial. The Journal of the American Medical Association, 297 (19), 2081-2091.

Čekanavičius, V., Murauskas, G. (2002). Statistika ir jos taikymas. Vilnius: TEV.

Dollman, J., Olds, T. (2007). Distributional changes in the performance of Australian children on tests of cardiorespiratory endurance. Medicine and Science in Sport and Exercise, 50, 210-225.

Eurofit, European Tests of Physical Fitness. (1993). Strasbourg: Council of Europe Committee for Development of Sport.

Guidelines for data processing and analysis of the International Physical Activity Questionnaire (IPAQ) - short and long forms. (2005). International Physical Activity Questionnaire [Žiūrèta 200805 10]. Prieiga internetu: < http://www.ipaq.ki.se >

Haskell, W. L. (1994). Dose-response issues from a biological perspective. In: R. J. Bouchard, R. J. Shepard, T. Stevens (Eds.), Physical Activity, Fitness, and Health (pp. 1030-1039). Champaign, IL: Human Kinetics.

Horst, K., Paw, J. C. A, Twisk, J. W. R., Mechelen, W. (2007). A brief review on correlates of physical activity and sedentariness in youth. Medicine and Science in Sport and Exercise, 39 (8), 1241-1250.
Howley, E. T. (2001). Type of activity: Resistance, aerobic and leisure versus occupational physical activity. Medicine and Science in Sport and Exercise, 33 (6), 364-369.

Katzmarzyk, P. T., Malina, R. M., Bouchard, C. (1999). Physical activity, physical fitness, and coronary heart disease risk factors in youth: The Quebec family study. Preventive Medicine, 29 (6), 555-562.

Lohman, T. G., Ring, K., Pfeiffer, K. et al. (2008). Relationships among fitness, body composition, and physical activity. Medicine and Science in Sport and Exercise, 40 (6), 1163-1170.

Malina, R. M., Bouchard, C., Bar-Or, O. (2004). Growth, Maturation, and Physical Activity. Second Edition. Champaign, IL: Human Kinetics.

Malina, R. M. (2001). Physical activity and fitness: Pathways from childhood to adulthood. American Journal of Human Biology, 13 (2), 162-172.

Matton, L., Thomis, M., Wijndaele, K. et al. (2006). Tracking of physical fitness and physical activity from youth to adulthood in females. Medicine and Science in Sport and Exercise, 38 (6), 1114-1120.

Oja, P. (2001). Review Dose response between total volume of physical activity and health and fitness. Medicine and Science in Sport and Exercise, 33 (6), 428-437.

Ortega, F. B., Ruiz, J. R., Castillo, M. J., Sjostrom, M. (2008). Physical fitness in childhood and adolecsence: A powerful marker of health. International Journal of Obesity, 32 (1), 1-11.

Ruiz, J. R., Ortega, F. B., Meusel, D. et al. (2006). Cardiorespiratory fitness is associated with features of metabolic risk factors in children. Should cardiorespiratory fitness be assessed in a European health monitoring system? The European Youth Heart Study. Journal of Public Health, 14 (2), 94-102.

Saar, M., Jurimae, T. (2004). Relationships between anthropometry, physical activity and motor ability in 10-17 year-old Estonians. Journal of Human Movement Studies, 47 (1), 1-12.

Strong, W. B., Malina, R. M., Blimkie, C. J. R. et al. (2005). Evidence based physical activity for school-age youth. Journal of Pediatrics, 146 (6), 732-737.

Sulemena, H., Smolensky, M.H., Lai, D. (2006). Relationship between physical activity and body mass 
index in adolescents. Medicine and Science in Sport and Exercise, 38 (6), 1182-1186.

Suni, J., Oja, P., Laukkanen, R., Miilunpalo, S. et al. (1994). Test Manual for the Assessment of Health Related fitness. Finland, Tampere: President Urko Kaleva Kekkonen Institute for Health Promotion Research.

Tammelin, T., Ekelund, U., Remes, J., Simo, N. (2007). Physical activity and sedentary behaviors among Finnish youth. Medicine and Science in Sport and Exercise, 39 (7), 1067-1074.

Volbekienè, V., Emeljanovas, A., Rutkauskaitè, R. Trinkūnienè, L. (2008). Mokinių fizinio aktyvumo ir su sveikata susijusio fizinio pajėgumo tarpusavio ryšiai. Ugdymas. Küno kultūra. Sportas , 4 (71), 127-132.

Volbekienè, V, Griciūtè, A., Gaižauskienè, A. (2007). Lietuvos didžiujų miestų 5-11 klasių moksleivių su sveikata susijęs fizinis aktyvumas. Ugdymas. Kūno kultūra. Sportas, 2 (65), 71-77.

Volbekiene, V., Griciute, A. (2007). Health-related physical fitness among schoolchildren in Lithuania: A comparison from 1992 to 2002. Scandinavian Journal of Public Health, 35, 235-242.

Wedderkopp, N., Froberg, K., Hansen, H. S., Andersen, L. B. (2004). Secular trends in physical fitness and obesity in Danish 9-year-old girls and boys: Odense school child study and Danish substudy of the European Youth Heart Study. Scandinavian Journal of Medicine \& Science in Sports, 14, 150-155.

Westerstahl, M., Barnekow-Bergkvist, M., Hedberg, G., Jansson, E. (2003). Secular trends in body dimensions and physical fitness among adolescents in Sweden from 1974 to 1995. Scandinavian Journal of Medicine \& Science in Sports, 13, 128-137.

\title{
HEALTH-RELATED FITNESS CHANGES IN DIFFERENT PHYSICAL ACTIVITY CATEGORIES AMONG ADOLESCENTS OVER ONE YEAR PERIOD \\ Arūnas Emeljanovas, Vida Volbekienė, Renata Rutkauskaitė, Edita Maciulevičienė, Rita Sadzevičienè, Olegas Batutis \\ Lithuanian Academy of Physical Education, Kaunas, Lithuania
}

\begin{abstract}
Physical fitness is in part genetically determined, but it can also be greatly influenced by environmental factors. Physical activity is one of the main determinants of physical fitness and its effect may differ depending on the intensity. The beneficial effects of physical activity (PA) to physical fitness and to various health components are well established in adults although we lack studies on children and adolescents.

The aim of the research was to investigate the changes of health-related physical fitness of 15 and 16 year-old boys in different physical activity categories over the year.

The study was undertaken in March-April 2008 in randomly selected secondary schools of Kaunas. The participants were 118 healthy schoolboys of $9^{\text {th }}$ grade. PA was measured by a modified short form of an international PA questionnaire (IPAQ, Ainsworth, Levy, 2004). According to the recommendations of the Guidelines for Data Processing and Analysis of the International Physical Activity Questionnaire (IPAQ) (2005), all the respondents were divided into three PA categories: vigorous PA (VPA) $(\geq 3001$ MET$\mathrm{min} / \mathrm{wk})$, moderate PA (MPA) $(>1387<3001 \mathrm{MET}-\mathrm{min} / \mathrm{wk})$ and low PA (LPA) $(\leq 1387 \mathrm{MET}-\mathrm{min} / \mathrm{wk})$. The participants performed physical fitness tests to measure their flexibility (Eurofit, 1993), power (vertical jump was measured using a jump parameter gauge - SBM-1, taking into account one best jump of three), muscular strength and endurance (modified push-up test, Suni et al., 1994). Out of the original sample, 56 participants remained to undergo the identical measurements of HRF in March-April 2009. Appropriate statistical methods (one-way analysis of variance - ANOVA, parametrical $t$ test criterion for dependent samples, and analysis of covariance (ANCOVA), based upon the experimental design were applied.

The analysis indicated positive changes in muscular fitness i.e. endurance of arms and trunk muscles and power of legs muscles in adolescent boys if the amount of physical activity is greater $(p<0.05)$. Changes in flexibility relative to the greater amount of physical activity were not significant $(p>0.05)$.
\end{abstract}

Keywords: physical fitness, physical activity, health.

Gauta 2010 m. kovo 15 d.

Received on March 15, 2010

Priimta 2010 m. gegužès 31 d.

Accepted on May 31, 2010
Renata Rutkauskaitè

Lietuvos kūno kultūros akademija

(Lithuanian Academy of Physical Education)

Sporto g. 6, LT-44221 Kaunas

Lietuva (Lithuania)

Tel +370 37302669

E-mail r.rutkauskaite@1kka.lt 